\title{
Deficits in emotion processing in Alzheimer's disease: a systematic review
}

\author{
Rogeria Cristina Rangel da Silva ${ }^{\oplus}$, Raquel Luíza Santos de Carvalho² ${ }^{\odot}$, \\ Marcia Cristina Nascimento Dourado ${ }^{1} \odot$
}

\begin{abstract}
Emotional processing involves the ability of the individual to infer emotional information. There is no consensus about how Alzheimer's disease (AD) affects emotional processing. Objective: Our aim is to systematically review the impact of AD on emotion processing. Methods: We conducted a search based on the Preferred Reporting Items for Systematic Reviews and Meta-Analyses (PRISMA). The literature search was performed using the electronic databases MEDLINE (PubMed) and Science Citation Index (Institute for Scientific Information [ISI]). The following descriptors were used in the review process: emotion or emotional processing, cognition or cognitive functions, and Alzheimer disease or Alzheimer's disease. This systematic review was recorded in the International Prospective Register of Systematic Reviews (PROSPERO) under the number CRD42018115891. Results: We identified 425 articles, 19 of which met our criteria. Visual emotional stimuli were the most used among studies. Most studies used tasks of emotional naming, discrimination, identification, and correspondence. The results were contradictory. Many studies reported that individuals with $A D$ were impaired on emotional perception tasks, while other results reported preserved skills. The relationship between emotional processing and cognition is also unclear. Some studies suggested that general cognitive performance affects performance in emotional perception tasks among people with $A D$, but other studies have shown deficits in recognizing emotion, regardless of cognitive performance. Conclusions: Studies are scarce, present contradictory results, and report impairment in emotional processing in relation to cognition. Moreover, the analyses of the correlation between emotion processing and cognitive functioning failed to reveal clear relationships.
\end{abstract}

Keywords: Alzheimer's disease, cognition, emotion.

\section{DÉFICITS NO PROCESSAMENTO EMOCIONAL NA DOENÇA DE ALZHEIMER: UMA REVISÃO SISTEMÁTICA}

RESUMO. 0 processamento emocional é a habilidade de indivíduos inferirem informação emocional. Não há consenso sobre como a doença de Alzheimer (DA) afeta o processamento emocional. Objetivo: Este artigo visa revisar sistematicamente o impacto da DA no processamento emocional. Métodos: Realizamos uma pesquisa com base no Preferred Reporting Items for Systematic Reviews and Meta-Analyses (PRISMA). A pesquisa bibliográfica foi realizada nas bases de dados eletrônicas MEDLINE (Pubmed) e Science Citation Index (ISI). Os seguintes descritores foram utilizados no processo de revisão: processamento emocional ou emoção, cognição ou funções cognitivas e doença de Alzheimer. A revisão sistemática foi registrada no Registro Prospectivo Internacional de Revisões Sistemáticas (PROSPERO), sob o número CRD42018115891. Resultados: Foram identificados 425 artigos, 19 dos quais atendiam aos critérios de inclusão. Os estímulos visuais emocionais foram os mais utilizados entre os estudos. A maioria dos estudos usou tarefas de nomeação emocional, discriminação, identificação e correspondência. Os resultados foram contraditórios. Muitos estudos relataram que indivíduos com DA apresentavam comprometimento em tarefas de percepção emocional, outros resultados apontam para habilidades preservadas. A relação entre o processamento emocional e a cognição também não está clara. Alguns estudos sugerem que 0 desempenho cognitivo geral afeta 0 desempenho nas tarefas de percepção emocional na DA, outros estudos demonstraram déficits no reconhecimento da emoção, independentemente do desempenho cognitivo. Conclusões: Os estudos são escassos, apresentam resultados contraditórios e relatam comprometimento no processamento emocional em relação à cognição. Além disso, análises de correlação entre processamento emocional e funcionamento cognitivo não conseguiram revelar relações claras.

Palavras-chave: doença de Alzheimer, cognição, emoção.

This study was conducted by the.Center for Alzheimer's Disease, Institute of Psychiatry, Universidade Federal do Rio de Janeiro, Rio de Janeiro, RJ, Brazil. 'Center for Alzheimer's Disease, Institute of Psychiatry, Universidade Federal do Rio de Janeiro - Rio de Janeiro, RJ, Brazil. ${ }^{2}$ Universidade Grande Rio - Rio de Janeiro, RJ, Brazil.

Rogeria Cristina Rangel da Silva. Rua Gonzaga Bastos, 12 - Jardim Meriti - 25555-040 Rio de Janeiro RJ - Brazil. E-mail: rogeria.rangel@hotmail.com Disclosure: The authors report no conflicts of interest.

Funding: Marcia Cristina Nascimento Dourado is a researcher funded by the National Council for Scientific and Technological Development — CNPq, crant number $304461 / 2020-2$

Received on February 03, 2021. Accepted in final form on April 12, 2021

\section{(cc) BY}




\section{INTRODUCTION}

$\mathbf{T}$ motion processing refers to the cognitive processes Einvolved in the capacity of understanding other people's and/or one's own emotional state.1 Everyday emotions involve a blending of various bottom-up processing of encounters with emotional stimuli along with top-down conceptual knowledge, memories, and linguistic representations. ${ }^{2}$ Emotional perception may be impaired in healthy aging. ${ }^{3-5}$ Therefore, deficits in emotion processing can be a prominent clinical symptom after acute brain damage, such as traumatic brain injury or stroke, and can be a core feature of the early stages of some neurodegenerative disorders, such as behavioral-variant frontotemporal dementia. ${ }^{6-9}$

In the mild stages of Alzheimer's disease (AD), emotion processing impairments might be relatively subtle and harder to detect. ${ }^{8}$ People with AD tend to show decreased emotion processing with impaired identification, labeling, matching, and discrimination of emotions. ${ }^{6,7,10,11}$ Emotion processing has been examined through photos of faces expressing six basic emotions, namely, happiness, sadness, fear, anger, disgust, and surprise. ${ }^{12}$ Other instruments (i.e., emotional dynamic stimuli such as video clips and movie excerpts) may offer additional information about people with the emotional state of $\mathrm{AD}$. There is some evidence that decreased emotion processing among people with $\mathrm{AD}$ may be explained by the structural and functional changes within the frontal and temporal neuronal circuits. ${ }^{13,14} \mathrm{AD}$ pathology, particularly neurofibrillary tangles, initially affects the medial temporal lobe structures, including the entorhinal cortex, hippocampus, and amygdala. ${ }^{15,16}$ Various studies highlight the essential role of the amygdala in the emotion processing, ${ }^{17-20}$ which is supported by neuroimaging studies that show the alterations in the limbic system in people with $\mathrm{AD} .{ }^{21-24}$ Studies also suggest that people with AD showed impaired emotion recognition, especially for facial expressions. ${ }^{25-28}$ However, others have shown that decoding of emotions is comparable in healthy older adults and people with $\mathrm{AD} \cdot{ }^{26}$ In addition, these difficulties do not seem to depend on disease severity. ${ }^{29,30}$

Specific emotions may vary in their vulnerability to AD pathology. Recent studies indicate that the capacity to identify happiness (i.e., positive emotions) is preserved in $\mathrm{AD}$, while decoding negative emotions seems impaired. ${ }^{16,27,31}$ The identification of disgust may be preserved, ${ }^{25}$ while decoding fear is impaired. ${ }^{6,11,25,27,32-34}$ There are controversies about people with $\mathrm{AD}$ ability to recognizesadness, anger, and surprise ${ }^{11,27,34,35}$.Therefore, we may assume that in $\mathrm{AD}$, the emotion processing is differently affected, and that the identification of some specific emotions may be impacted, while others are not.
Although it was not consistently demonstrated throughout the literature, ${ }^{6,10,36}$ some authors also suggested that the observed impairment of emotion processing tasks in $\mathrm{AD}$ is not necessarily related to impaired emotional decoding abilities, but may, in fact, occur secondary to generalized global cognitive decline. ${ }^{1,13,34,37,38}$ However, other authors did not obtain the same results and concluded that people with $\mathrm{AD}$ may present impaired emotional recognition per se. Thus, given the current controversial results about the impairment of emotion processing in $\mathrm{AD}$, we hypothesized that people with $\mathrm{AD}$ may have an impaired capacity of processing emotional information even in the mild stages of the disease. Deficits in emotion processing have been associated with negative caregiver outcomes ${ }^{39}$ and functional disability ${ }^{8}$ in AD. Therefore, in this systematic review, we aimed to better understand the extent to which emotion processing is impaired in people with $\mathrm{AD}$.

\section{METHODS}

This systematic review has been performed according to the Preferred Reporting Items for Systematic Reviews and Meta-Analyses (PRISMA). We searched the Thomson Reuters Web of Science (Institute for Scientific Information - ISI) and MEDLINE (PubMed), including articles published from January 1, 2009, and November 11, 2019, in English, which presented studies with cross-sectional or longitudinal designs about the relationship between emotion processing and cognition among people with $\mathrm{AD}$.

We applied the key words "emotion," "emotional processing," "cognition," and "Alzheimer's disease" in different combinations for each database. For MEDLINE (PubMed), we applied the following combinations: (emotional processing OR emotional [MeSH Terms] OR emotion [MeSH Terms]) AND (alzheimer disease OR alzheimer's disease [MeSH Terms]) AND (cognition AND cognitive functions [MeSH Terms]), with the following filters: Humans, English, and Publication Date from 2009/01/01 to 2019/11/01.

For the identification of articles in the Thomson Reuters Web of Science (ISI), we applied the following search strategy: \#1 (TS=(alzheimer disease OR alzheimer's disease) \#2 (TS=(emotion OR emotional processing) \#3 (TS= (cognition OR cognitive functions OR cognitive functioning) \#3 AND \#2 AND \#. We also applied the following filters: Language: English; types of documents: articles; and date range: 2009-2019. The exclusion criteria included systematic reviews, meta-analysis, articles with no casuistic, and case reports or studies about emotion processing and cognition in other diseases. Initial article-screening was performed by two authors 
via abstract review. We excluded articles that clearly did not fulfill the inclusion criteria, and we maintained the ones that were possibly eligible. When there was not a consensus among the two authors, the article remained as potentially eligible and was included in the next assessment of eligibility. Disagreement between both authors was solved by an independent author.

The selected articles from the first phase were read by two independent authors to adjust eligibility. In this phase, the main exclusion criteria for each study were registered in the PRISMA flowchart (Figure 1) to compose the flow of article selection.

To maintain the standard suggested by the PRISMA method, this systematic review was registered in the International Prospective Register of Ongoing Systematic Reviews (PROSPERO) as CRD42018115891.

All the included articles were submitted to the Mixed Methods Appraisal Tool version 2018, ${ }^{40}$ a tool of critical assessment that evaluates the quality of empirical studies.

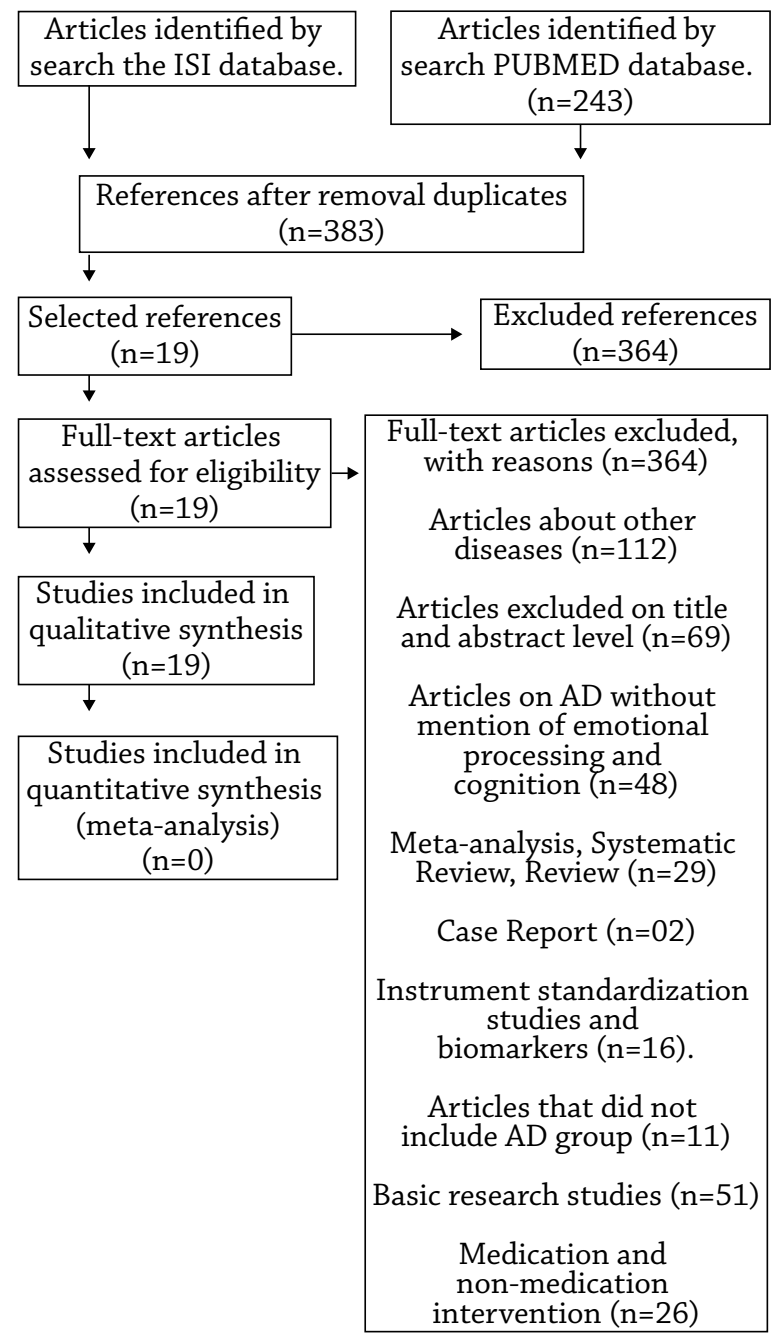

Figure 1. Flow-chart of article selection.

\section{RESULTS}

We found 425 articles, 182 on the ISI database and 243 on PubMed/MEDLINE. After excluding the cross-references $(n=42)$, we selected 383 articles. The excluded articles $(\mathrm{n}=364)$ were selected and analyzed according to the eligibility criteria. The exclusion flowchart of selected articles is described in Figure 1.

We included the complete version of the remaining 19 articles. The selected articles were fully accessed and independently organized as shown in Table 1 that contained the following information: author/year, design, sample, operationalization of $\mathrm{AD}$ diagnosis, objective, emotional processing evaluation, cognitive evaluation, and quality assessment.

\section{Sample}

From the 19 articles analyzed in this review, 16 studies compared AD with a control group..$^{39,41-55}$ One study assessed people with $\mathrm{AD}$ in mild and moderate stages. ${ }^{56}$ Seidl et al. ${ }^{57}$ assessed one group of 47 individuals with $\mathrm{AD}$, but they did not specify the stage of disease severity. In Torres et al., ${ }^{58}$ the comparison was performed in two different moments of people with mild AD.

\section{Operationalization of Alzheimer's disease diagnosis}

Diagnoses of possible or probable $\mathrm{AD}$ in 13 studies were made according to the criteria of the National Institute of Neurological and Communicative Disorders and Stroke and the Alzheimer's Disease and Related Disorders Association (NINCDS/ADRDA) ${ }^{39,41-49,52-54,57}$ or based on the $\mathrm{Di}$ agnostic and Statistical Manual of Mental Disorders, Fourth Edition (DSM-IV) guidelines. ${ }^{50,51,56,58}$ Computed tomography and/or magnetic resonance imaging examinations were occasionally used to support the diagnosis. $41,48,53,54,56,58$ The specific diagnostic criteria used to identify possible or probable $\mathrm{AD}$ were unclear in one study. ${ }^{55}$

\section{Degree of severity in Alzheimer's disease}

Of the 19 studies, 8 studies analyzed the impairment in patients with $\mathrm{AD}$ at mild and moderate levels, ${ }^{42,43,46-48,50,51,56}$ 5 studies evaluated individuals with mild $\mathrm{AD},{ }^{49,53-55,58}$ and 6 studies did not measure staging or the severity of the disease in the participants of the $\mathrm{AD}$ group. . $^{39,41,44,45,52,57}$

\section{ASSESSMENT CRITERIA}

Tasks with various visual stimuli were most frequently applied. In 14 studies, images or drawings were applied. ${ }^{39,41,42,48,49-58}$ Images of facial expressions in black and white were applied in three studies. ${ }^{52,54,55}$ Color images of natural or manufactured objects were applied in three studies. ${ }^{41,48,49}$ Two studies applied movies ${ }^{42,50}$ 
Table 1. Characteristics of the studies.

\begin{tabular}{|c|c|c|c|c|c|c|c|}
\hline $\begin{array}{l}\text { Authors, } \\
\text { year }\end{array}$ & Design & Sample & AD diagnosis & Objective & $\begin{array}{l}\text { Emotional } \\
\text { processing } \\
\text { evaluation }\end{array}$ & $\begin{array}{l}\text { Cognitive } \\
\text { evaluation }\end{array}$ & $\begin{array}{c}\text { Quality } \\
\text { assessment }\end{array}$ \\
\hline $\begin{array}{l}\text { Bourgin, } \\
2018^{41}\end{array}$ & $\begin{array}{l}\text { Cross- } \\
\text { sectional }\end{array}$ & $\begin{array}{c}\text { AD } 16 \\
\text { HOAs } 25\end{array}$ & $\begin{array}{l}\text { NINCDS-ADRDA } \\
\text { Imaging exams }\end{array}$ & $\begin{array}{l}\text { To determine whether } \\
\text { early emotional attention } \\
\text { mechanisms are affected } \\
\text { by } A D .\end{array}$ & $\begin{array}{l}\text { An eye-tracking } \\
\text { technique during a } \\
\text { simple but time- } \\
\text { constrained cognitive } \\
\text { task. }\end{array}$ & $\begin{array}{c}\text { MMSE } \\
\text { BDI }\end{array}$ & 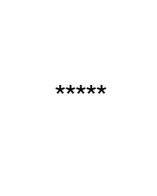 \\
\hline $\begin{array}{l}\text { Daley, } \\
2018^{39}\end{array}$ & $\begin{array}{l}\text { Cross- } \\
\text { sectional }\end{array}$ & $\begin{array}{l}A D=28 \\
0 C s 30\end{array}$ & NINCDS-ADRDA & $\begin{array}{l}\text { To investigate the } \\
\text { relationship between } \\
\text { emotional perception } \\
\text { abilities in AD participants } \\
\text { and CG well-being. }\end{array}$ & $\begin{array}{l}\text { Advanced Clinical } \\
\text { Solutions Social } \\
\text { Perception subtest } \\
\text { (ACS-SP) }\end{array}$ & $\begin{array}{c}\text { Montreal } \\
\text { Cognitive } \\
\text { Assessment } \\
\text { (MoCA). }\end{array}$ & $\star \star \star \star \star *$ \\
\hline $\begin{array}{l}\text { Dourado, } \\
2019^{56}\end{array}$ & $\begin{array}{l}\text { Cross- } \\
\text { sectional }\end{array}$ & $\begin{array}{l}52 \text { participants } \\
\text { AD (mild } n=29 \text {; } \\
\text { moderate } n=23 \text { ) }\end{array}$ & $\begin{array}{c}\text { DSM-IV-TR } \\
\text { Imaging exams }\end{array}$ & $\begin{array}{l}\text { To compare facial } \\
\text { expression recognition } \\
\text { in this AD sample and } \\
\text { to identify which factors } \\
\text { were associated with the } \\
\text { impairment of the ability } \\
\text { according to disease } \\
\text { severity }\end{array}$ & The protocol FACES & $\begin{array}{l}\text { Assessment } \\
\text { Scale- Cognitive } \\
\text { Subscale (ADAS- } \\
\text { Cog), MMSE, } \\
\text { Wechsler Digit } \\
\text { Span Test, TMT } \\
\text { And Semantic } \\
\text { fluency tests }\end{array}$ & 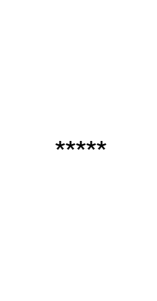 \\
\hline $\begin{array}{l}\text { Duclos, } \\
2018^{42}\end{array}$ & $\begin{array}{l}\text { Cross- } \\
\text { sectional }\end{array}$ & $\begin{array}{c}n=60 \\
A D 20 \\
\text { HOS } 20 \text { and } \\
\text { HYS } 20\end{array}$ & NINCDS-ADRDA & $\begin{array}{l}\text { To assess both decoding } \\
\text { and reasoning processes } \\
\text { in } A D \text {, as well as the effect } \\
\text { of context on emotion } \\
\text { attribution }\end{array}$ & $\begin{array}{l}\text { Peter and Mary } \\
\text { emotion tasks } \\
\text { Battery }\end{array}$ & MMSE & 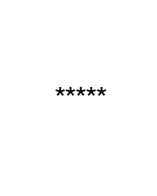 \\
\hline $\begin{array}{l}\text { Giffard, } \\
2009^{43}\end{array}$ & $\begin{array}{l}\text { Cross- } \\
\text { sectional }\end{array}$ & $\begin{array}{l}\text { AD } 26 \\
\text { CG } 26\end{array}$ & NINCDS-ADRDA & $\begin{array}{l}\text { To introduce and control } \\
\text { the emotional nature } \\
\text { of concepts in order to } \\
\text { conduct a more ecological } \\
\text { investigation of semantic } \\
\text { memory in AD using a } \\
\text { semantic and affective } \\
\text { priming paradigm. }\end{array}$ & $\begin{array}{c}\text { The lexical decision } \\
\text { task was composed } \\
\text { of } 270 \text { pairs of } \\
\text { stimuli. }\end{array}$ & MDRS & 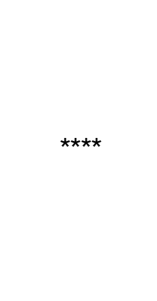 \\
\hline $\begin{array}{l}\text { Kalenzaga, } \\
2013^{44}\end{array}$ & $\begin{array}{l}\text { Cross- } \\
\text { sectional }\end{array}$ & $\begin{array}{l}\text { AD } 22 \\
C G 21\end{array}$ & NINCDS-ADRDA & $\begin{array}{l}\text { To explore the impairment in } \\
\text { patients with } A D \text { working self } \\
\text { with regard to the affective } \\
\text { dimension of } A D .\end{array}$ & $\begin{array}{l}\text { Remember/Know/ } \\
\text { Guess paradigm } \\
\text { following encoding of } \\
\text { emotional and neutral } \\
\text { words. }\end{array}$ & $\begin{array}{l}\text { MDRS } \\
\text { MMSE }\end{array}$ & $\star \star \star \star *$ \\
\hline $\begin{array}{l}\text { Kalenzaga, } \\
2013^{45}\end{array}$ & $\begin{array}{l}\text { Cross- } \\
\text { sectional }\end{array}$ & $\begin{array}{l}n=40 \\
A D 22 \\
\text { CG } 18\end{array}$ & NINCDS-ADRDA & $\begin{array}{l}\text { To investigate the effect of } \\
\text { emotional words encoded } \\
\text { with reference to the self on } \\
\text { the state of consciousness } \\
\text { associated with memory } \\
\text { retrieval in AD. }\end{array}$ & $\begin{array}{l}\text { Remember/Know/ } \\
\text { Guess paradigm } \\
\text { following encoding of } \\
\text { emotional and neutral } \\
\text { words. }\end{array}$ & $\begin{array}{l}\text { MMSE } \\
\text { MDRS }\end{array}$ & $\star \star \star \star *$ \\
\hline $\begin{array}{l}\text { Kalenzaga, } \\
2014^{46}\end{array}$ & $\begin{array}{l}\text { Cross- } \\
\text { sectional }\end{array}$ & $\begin{array}{l}n=33 \\
A D 18 \\
C G 15\end{array}$ & NINCDS-ADRDA & $\begin{array}{l}\text { To investigate emotional } \\
\text { memory enhancement } \\
\text { (EME) in AD. And in exploring } \\
\text { which memory process (i.e., } \\
\text { recollection or familiarity) } \\
\text { could be improved by } \\
\text { emotional information in the } \\
\text { course of the disease. }\end{array}$ & $\begin{array}{l}\text { Remember/Know/ } \\
\text { Guess paradigm } \\
\text { following encoding of } \\
\text { emotional and neutral } \\
\text { words. }\end{array}$ & MDRS & $* * * *$ \\
\hline
\end{tabular}


Table 1. Continuation.

\begin{tabular}{|c|c|c|c|c|c|c|c|}
\hline $\begin{array}{l}\text { Authors, } \\
\text { year }\end{array}$ & Design & Sample & AD diagnosis & Objective & $\begin{array}{l}\text { Emotional } \\
\text { processing } \\
\text { evaluation }\end{array}$ & $\begin{array}{l}\text { Cognitive } \\
\text { evaluation }\end{array}$ & $\begin{array}{c}\text { Quality } \\
\text { assessment }\end{array}$ \\
\hline
\end{tabular}

\begin{tabular}{|c|c|c|c|c|c|c|c|}
\hline $\begin{array}{l}\text { Kalenzaga, } \\
2016^{47}\end{array}$ & $\begin{array}{l}\text { Cross- } \\
\text { sectional }\end{array}$ & $\begin{array}{l}n=155 \\
\text { YA } 38 \\
\text { OA } 39 \\
\text { VOA } 37 \\
\text { AD } 41\end{array}$ & NINCDS-ADRDA & $\begin{array}{l}\text { To introduce some elements } \\
\text { concerning positivity effect } \\
\text { in aging }\end{array}$ & $\begin{array}{l}\text { Emotional valence } \\
\text { rating using an } \\
\text { 8-point scale (1 } \\
\text { highly negative, } 8 \\
\text { highly positive). }\end{array}$ & MMSE & 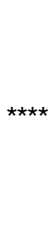 \\
\hline
\end{tabular}

\begin{tabular}{|c|c|c|c|c|c|c|c|}
\hline $\begin{array}{l}\text { Laisney, } \\
2013^{48}\end{array}$ & $\begin{array}{l}\text { Cross- } \\
\text { sectional }\end{array}$ & $\begin{array}{l}16 \mathrm{AD} \\
15 \mathrm{CG}\end{array}$ & NINCDS-ADRDA & $\begin{array}{l}\text { To investigate changes in } \\
\text { the cognitive and affective } \\
\text { dimensions of ToM in } A D\end{array}$ & $\begin{array}{l}\text { Affective ToM was } \\
\text { assessed via a } \\
\text { modified version of } \\
\text { the Reading the Mind } \\
\text { in the Eyes test }\end{array}$ & $\begin{array}{c}\text { Cognitive ToM } \\
\text { was assessed } \\
\text { by means of } \\
\text { preference } \\
\text { judgment (PJ) } \\
\text { and FB tasks. }\end{array}$ & 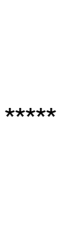 \\
\hline
\end{tabular}

\begin{tabular}{|c|c|c|c|c|c|c|c|}
\hline $\begin{array}{l}\text { Maki, } \\
2013^{49}\end{array}$ & $\begin{array}{l}\text { Cross- } \\
\text { sectional }\end{array}$ & $\begin{array}{c}n=54 \\
\text { AD } 12 \\
\text { ANC } 17 \\
\text { YNC } 25\end{array}$ & NINCDS-ADRDA & $\begin{array}{l}\text { To examine whether } \\
\text { recognition of positive facial } \\
\text { expressions is preserved in } \\
\text { patients with } A D\end{array}$ & $\begin{array}{l}\text { DB99 (Advanced } \\
\text { Telecommunications } \\
\text { Research Institute } \\
\text { International) }\end{array}$ & CDR & 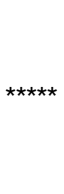 \\
\hline
\end{tabular}

\begin{tabular}{|c|c|c|c|c|c|c|c|}
\hline $\begin{array}{l}\text { Mograbi, } \\
2012^{50}\end{array}$ & $\begin{array}{l}\text { Cross- } \\
\text { sectional }\end{array}$ & $\begin{array}{l}n=43 \\
A D 22 \\
\text { CG } 21\end{array}$ & DSM-IV-TR & $\begin{array}{l}\text { To explore emotional } \\
\text { reactivity in mild to } \\
\text { moderate } A D \text { using film } \\
\text { material, investigating the } \\
\text { influence of dementia- } \\
\text { related material and } \\
\text { awareness of condition. }\end{array}$ & $\begin{array}{l}\text { The rating of facial } \\
\text { expressions was } \\
\text { made with EMFACS, } \\
\text { a selective system } \\
\text { based on the Facial } \\
\text { Action Coding System } \\
\text { (FACS). }\end{array}$ & $\begin{array}{l}\text { MMSE, } \\
\text { CERAD }\end{array}$ & 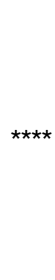 \\
\hline
\end{tabular}

\begin{tabular}{|c|c|c|c|c|c|c|c|}
\hline $\begin{array}{l}\text { Mograbi, } \\
2012^{51}\end{array}$ & $\begin{array}{l}\text { Cross- } \\
\text { sectional }\end{array}$ & $\begin{array}{l}\text { AD } 23 \\
\text { CG } 21\end{array}$ & DSM-IV-TR & $\begin{array}{l}\text { To investigate emotional } \\
\text { reactions to success } \\
\text { or failure in tasks } \\
\text { despite unawareness of } \\
\text { performance in } A D \text {. }\end{array}$ & $\begin{array}{l}\text { The rating of facial } \\
\text { expressions was } \\
\text { made with EMFACS, } \\
\text { a selective system } \\
\text { based on the Facial } \\
\text { Action Coding System } \\
\text { (FACS). } \\
\text { and Mann-Whitney } \\
\text { U-test. }\end{array}$ & MMSE, CERAD & 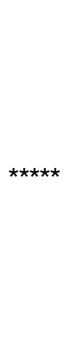 \\
\hline $\begin{array}{l}\text { Monti, } \\
2010^{52}\end{array}$ & $\begin{array}{l}\text { Cross- } \\
\text { sectional }\end{array}$ & $\begin{array}{l}\text { PRAD } 19 \\
\text { HEA } 15 \\
\text { HYA } 22\end{array}$ & NINCDS-ADRDA & $\begin{array}{c}\text { To evaluate the efficacy } \\
\text { of non-emotional and } \\
\text { emotional conflict } \\
\text { adaptation mechanisms } \\
\text { in healthy young, healthy } \\
\text { elderly, and PRAD. }\end{array}$ & $\begin{array}{c}\text { Presentation software } \\
\text { Pictures of Facial } \\
\text { Affect FACS }\end{array}$ & CDR & 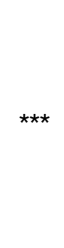 \\
\hline $\begin{array}{l}\text { Sapey, } \\
2015^{53}\end{array}$ & $\begin{array}{l}\text { Cross- } \\
\text { sectional }\end{array}$ & $\begin{array}{l}\mathrm{n}=78 \\
\text { AD } 39 \\
\text { HC } 39\end{array}$ & NINCDS-ADRDA & $\begin{array}{c}\text { To better specify the } \\
\text { early emotion recognition } \\
\text { deficits at mild stages of } \\
A D \text { and to disentangle their } \\
\text { neuroanatomical correlates. }\end{array}$ & $\begin{array}{l}\text { Facial emotional } \\
\text { expression } \\
\text { recognition task. }\end{array}$ & MMSE, CDR & 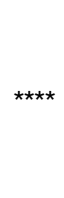 \\
\hline
\end{tabular}


Table 1. Continuation.

\begin{tabular}{|c|c|c|c|c|c|c|c|}
\hline $\begin{array}{l}\text { Authors, } \\
\text { year }\end{array}$ & Design & Sample & AD diagnosis & Objective & $\begin{array}{l}\text { Emotional } \\
\text { processing } \\
\text { evaluation }\end{array}$ & $\begin{array}{l}\text { Cognitive } \\
\text { evaluation }\end{array}$ & $\begin{array}{c}\text { Quality } \\
\text { assessment }\end{array}$ \\
\hline $\begin{array}{l}\text { Sava, } \\
2017^{54}\end{array}$ & $\begin{array}{l}\text { Cross- } \\
\text { sectional }\end{array}$ & $\begin{array}{l}\mathrm{n}=63 \\
\mathrm{AD} 17 \\
\mathrm{H} 021 \\
\mathrm{HYs} 25 \\
\mathrm{n}=60 \\
\mathrm{AD} 18 \\
\mathrm{H} 021 \\
\text { HYs } 21\end{array}$ & $\begin{array}{l}\text { NINCDS-ADRDA } \\
\text { Brain morphology } \\
\text { imaging }\end{array}$ & $\begin{array}{l}\text { To compare the memory } \\
\text { performance of healthy } \\
\text { young and older participants } \\
\text { and patients with AD for } \\
\text { faces with positive, neutral, } \\
\text { and negative emotional } \\
\text { expressions in tasks in } \\
\text { which memory performance } \\
\text { could not be enhanced by } \\
\text { familiarity. }\end{array}$ & $\begin{array}{l}\text { Montreal Set of Facial } \\
\text { Displays of Emotion }\end{array}$ & MMSE & $\star \star * \star * *$ \\
\hline $\begin{array}{l}\text { Seid, } \\
2012^{57}\end{array}$ & $\begin{array}{l}\text { Cross- } \\
\text { sectional }\end{array}$ & AD 47 & NINCDS-ADRDA & $\begin{array}{c}\text { To explore the determinants } \\
\text { of emotional facial } \\
\text { expression in } A D \text { and } \\
\text { to address the impact } \\
\text { of cognitive and } \\
\text { neuropsychiatric symptoms, } \\
\text { which were considered } \\
\text { as potential moderating } \\
\text { variables. }\end{array}$ & $\begin{array}{c}\text { International affective } \\
\text { picture system (IAPS). } \\
\text { The rating of facial } \\
\text { expressions was } \\
\text { made with EMFACS, } \\
\text { a selective system } \\
\text { based on the Facial } \\
\text { Action Coding System } \\
\text { (FACS). }\end{array}$ & $\begin{array}{c}\text { MMSE, GDS, } \\
\text { NPI } \\
\text { AES }\end{array}$ & 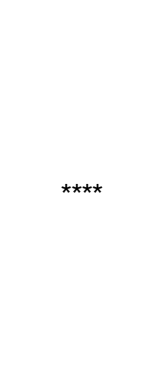 \\
\hline $\begin{array}{l}\text { Torres, } \\
2015^{58}\end{array}$ & Longitudinal & AD 30 & $\begin{array}{c}\text { DSM-IV-TR } \\
\text { And } \\
\text { NINCDS-ADRDA }\end{array}$ & $\begin{array}{l}\text { To investigate the patterns } \\
\text { of change in the ability to } \\
\text { recognize emotions in facial } \\
\text { expressions among people } \\
\text { with mild } A D \text { and to explore } \\
\text { the sociodemographic and } \\
\text { clinical factors that may } \\
\text { influence facial emotion } \\
\text { recognition in } A D \text { over time }\end{array}$ & The protocol FACES & $\begin{array}{c}\text { CDR } \\
\text { MMSE }\end{array}$ & 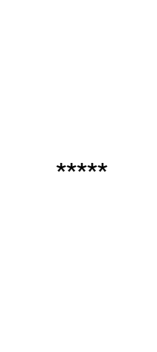 \\
\hline $\begin{array}{l}\text { Werheid, } \\
2011^{55}\end{array}$ & $\begin{array}{l}\text { Cross- } \\
\text { sectional }\end{array}$ & $\begin{array}{l}\text { AD } 18 \\
\text { CG } 18\end{array}$ & Not reported & $\begin{array}{l}\text { To compare patients with } \\
\text { mild } A D \text { and age-matched } \\
\text { healthy adults with respect } \\
\text { to performance in a } \\
\text { recognition task involving } \\
\text { positive, negative, and } \\
\text { neutral faces. }\end{array}$ & $\begin{array}{c}\text { Benton Facial } \\
\text { Recognition Test } \\
\text { PANAS }\end{array}$ & $\begin{array}{l}\text { MEEM } \\
\text { CERAD }\end{array}$ & 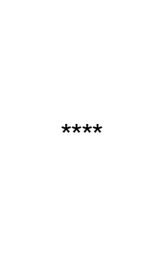 \\
\hline
\end{tabular}

AD: Alzheimer's disease; $\left.{ }^{\star \star \star \star}\right)$ Quality assessment, ADAS-Cog: Assessment Scale-Cognitive Subscale; AES: Apathy Evaluation Scale; ANC: aged normal controls; BDI: Beck Depression Inventory; CDR: Clinical Dementia Rating scale; CERAD: Consortium to establish a registry for Alzheimer's disease; CG: control group; DSM-IV-TR: Diagnostic and Statistical Manual of Mental Disorders, Fourth Edition; FB: false belief; GDS: Global Deterioration Scale; HC: healthy control; HEA: healthy elderly adults; HO: healthy older; HOAs: healthy older adults; HOS: healthy older individuals; HYA: healthy young adults; HYs: healthy young individuals; IAPS: international affective picture system; MDRS: Mattis Dementia Rating Scale; MMSE: Mini-Mental State Examination; MoCA: Montreal Cognitive Assessment; NINCDS-ADRDA: National Institute of Neurological and Communicative Diseases and Stroke/Alzheimer's Disease and Related Disorders Association; NPI: Neuropsychiatric Inventory; OA: older adults; OCs: older controls; PANAS: Positive and Negative Affect Schedule; PJ: preference judgment; PRAD: probable Alzheimer's disease; TMT: Trail Making Test; ToM: Theory of Mind; VOA: very old adults; YA: young adults; YNC: young normal controls.

using movie excerpts and a short black-and-white video. Finally, one study ${ }^{51}$ also applied two computerized paradigms of success-failure manipulation.

The five remaining studies used a word list as a stimulus. ${ }^{43-47}$ The words in word lists were classified as positive, negative, and neutral, ${ }^{43,47}$ as well as adjective lists related to personality traits ${ }^{44,45}$ and noun lists standardized by Bonin et al. ${ }^{46,59}$ in which the words were classified according to emotional state using a 5-point scale from 1 as "very unpleasant" to 5 as "very pleasant." 
From the 19 studies, 9 studies analyzed the following basic emotions: happiness, surprise, anger, sadness, fear, and disgust. Four studies included facial expressions of fear, ${ }^{39,49,52,53}$ and the facial expression of surprise was investigated in five studies. ${ }^{39,42,49,56,58}$ Only three studies analyzed the recognition of facial expressions of disgust, ${ }^{39,49,53}$ and four studies ${ }^{39,53-55}$ also included neutral expressions. Dynamic emotional stimuli such as video clips and short movie excerpts were used to assess the emotional processing in two studies. ${ }^{42,50}$

\section{TASKS FOR ASSESSMENT}

The assessment tasks were frequently divided into complementing stages according to the level of required cognitive effort. These stages were frequently identified in the studies as emotion identification, discrimination, selection, and correspondence of emotions. These procedures assess various cognitive competences and are considered the first step of emotion processing impairment analysis. Table 2 shows a summary of the specific tasks used in each initial study and includes the main results.

Table 2. Tasks and stimuli for the evaluation of emotion processing.

\begin{tabular}{|c|c|c|c|c|c|c|}
\hline S. No. & $\begin{array}{c}\text { Author, } \\
\text { Year }\end{array}$ & Sample & Stimuli and emotions & Tasks & Control tasks & Results \\
\hline 01 & $\begin{array}{c}\text { Bourgin, } \\
2018^{41}\end{array}$ & $\begin{array}{c}A D=16 \\
H O A s=25\end{array}$ & $\begin{array}{l}\text { The stimuli were } 96 \\
\text { color images of natural } \\
\text { or manufactured } \\
\text { objects, presented } \\
\text { against a white } \\
\text { background at a visual } \\
\text { angle of } 9 \times 9 \text {. }\end{array}$ & $\begin{array}{l}\text { Saccadic task involving } \\
\text { both prosaccades and } \\
\text { antisaccades. }\end{array}$ & $\begin{array}{l}\text { An eye-tracking technique } \\
\text { during a simple but time- } \\
\text { constrained cognitive task }\end{array}$ & $\begin{array}{l}\text { The results suggest that } \\
\text { early emotional attention } \\
\text { is indeed impaired in } A D\end{array}$ \\
\hline 02 & $\begin{array}{l}\text { Daley, } \\
2018^{39}\end{array}$ & $\begin{array}{l}A D=28 \\
C G=28 \\
0 C s=30\end{array}$ & $\begin{array}{l}\text { The Advanced Clinical } \\
\text { Solutions Social } \\
\text { Perception subtest } \\
\text { (ACS-SP) to measure } \\
\text { emotional perception } \\
\text { abilities). } \\
\text { Happy, sad, angry, } \\
\text { disgusted, afraid, } \\
\text { surprised, or neutral. }\end{array}$ & $\begin{array}{l}\text { The Affect Naming task, } \\
\text { the Prosody-Face Matching } \\
\text { task, and the Prosody-Pair } \\
\text { Matching task. }\end{array}$ & $\begin{array}{l}\text { Emotion identification, } \\
\text { emotion discrimination, and } \\
\text { emotion matching. }\end{array}$ & $\begin{array}{l}\text { The patient group } \\
\text { performed significantly } \\
\text { worse than control group } \\
\text { on measures of cognition } \\
\text { and emotional perception }\end{array}$ \\
\hline 03 & $\begin{array}{c}\text { Dourado, } \\
2019^{56}\end{array}$ & $\begin{array}{c}52 \\
\text { participants } \\
\text { AD mild } n=29 \\
\text { AD moderate } \\
n=23\end{array}$ & $\begin{array}{c}\text { Face drawings } \\
\text { Sadness, happiness, } \\
\text { anger, or surprise }\end{array}$ & $\begin{array}{l}\text { Matching: instructions- } \\
\text { match target face with } \\
\text { one of four alternatives; } \\
\text { point/verbal response to } \\
\text { another example of same } \\
\text { emotion and three other } \\
\text { expressions. Selection: } \\
\text { instructions-point to the } \\
\text { sad faces/choose face that } \\
\text { matches situation; point } \\
\text { response to one of four } \\
\text { alternatives. }\end{array}$ & $\begin{array}{l}\text { The subjects must } \\
\text { select the target of three } \\
\text { other distractors in the } \\
\text { same category. Identity } \\
\text { discrimination: (same/ } \\
\text { different emotion). Indicate } \\
\text { which of the four drawings } \\
\text { best depicts that specific } \\
\text { emotion. And indicate the } \\
\text { drawing that best described } \\
\text { the emotion he had inferred } \\
\text { from the stimulus. }\end{array}$ & $\begin{array}{l}\text { Emotional processing } \\
\text { difficulties across AD } \\
\text { stages. However, when } \\
\text { participants needed } \\
\text { to recognize the most } \\
\text { salient emotion in a } \\
\text { situation with evident } \\
\text { emotional content, the } \\
\text { results suggest that in } \\
\text { both groups, there was } \\
\text { no influence of cognitive } \\
\text { impairment. }\end{array}$ \\
\hline 04 & $\begin{array}{l}\text { Duclos, } \\
2018^{42}\end{array}$ & $\begin{array}{l}n=60 \\
A D 20 \\
\text { HOS } 20 \\
\text { HYS } 20\end{array}$ & $\begin{array}{l}\text { The Peter and Mary } \\
\text { emotion tasks Battery. } \\
\text { Two basic emotions (i.e., } \\
\text { anger and surprise), } \\
\text { two self-consciousness } \\
\text { emotions (i.e., } \\
\text { embarrassment and } \\
\text { pride), plus the neutral } \\
\text { state. }\end{array}$ & $\begin{array}{c}\text { (1) context task, (2) face } \\
\text { task, and (3) context-face } \\
\text { task }\end{array}$ & $\begin{array}{l}\text { Identification of emotions } \\
\text { (What is the emotion } \\
\text { expressed by the character?), } \\
\text { Discrimination of emotions } \\
\text { (Which of the four situations } \\
\text { could induce that emotion), } \\
\text { Correspondence of emotions } \\
\text { (Does the emotion expressed } \\
\text { by the character correspond } \\
\text { to the context?). }\end{array}$ & $\begin{array}{l}\text { The results suggest that } \\
\text { patients with AD have } \\
\text { difficulty attributing } \\
\text { emotional mental states, } \\
\text { and deficits in social } \\
\text { norm knowledge and the } \\
\text { presence of incongruent } \\
\text { information may heighten } \\
\text { this difficulty. }\end{array}$ \\
\hline
\end{tabular}


Table 2. Continuation.

\begin{tabular}{|c|c|c|c|c|c|c|}
\hline S. No. & $\begin{array}{l}\text { Author, } \\
\text { Year }\end{array}$ & Sample & Stimuli and emotions & Tasks & Control tasks & Results \\
\hline 05 & $\begin{array}{l}\text { Giffard, } \\
2009^{43}\end{array}$ & $\begin{array}{l}\text { AD } 26 \\
\text { CG } 26\end{array}$ & $\begin{array}{c}\text { Lists of words } \\
\text { (neutral, positive, and } \\
\text { negative). }\end{array}$ & $\begin{array}{l}\text { Semantic priming task } \\
\text { The lexical decision task. }\end{array}$ & Identification of words & $\begin{array}{l}\text { The results show that } \\
\text { this emotional process } \\
\text { is preserved in } A D \text { and } \\
\text { may even help patients } \\
\text { to bind semantically } \\
\text { close emotional concepts } \\
\text { together more tightly. }\end{array}$ \\
\hline 06 & $\begin{array}{l}\text { Kalenzaga, } \\
2013^{44}\end{array}$ & $\begin{array}{l}\text { AD } 22 \\
\text { CG } 21\end{array}$ & $\begin{array}{c}\text { Two lists of } 30 \\
\text { personality trait } \\
\text { adjectives were selected } \\
\text { from a normalized pool. } \\
\text { Paradigms Remember/ } \\
\text { Know/Guess }\end{array}$ & Remember/Know/Guess. & $\begin{array}{l}\text { The participants were asked } \\
\text { to underline the words they } \\
\text { recognized from the study } \\
\text { list and to indicate whether } \\
\text { or not they had a conscious } \\
\text { recollection of the learning } \\
\text { sequence. }\end{array}$ & $\begin{array}{l}\text { Results indicate that } \\
\text { self-reference increased } \\
\text { autonoetic consciousness } \\
\text { only for emotional and } \\
\text { particularly negative trait } \\
\text { adjectives. }\end{array}$ \\
\hline 07 & $\begin{array}{l}\text { Kalenzaga, } \\
2013^{45}\end{array}$ & $\begin{array}{l}n=40 \\
A D 22 \\
\text { CG } 18\end{array}$ & $\begin{array}{c}\text { Two lists of } 30 \\
\text { personality trait } \\
\text { adjectives were selected } \\
\text { from a normalized pool. }\end{array}$ & Remember/Know/Guess. & $\begin{array}{l}\text { Read aloud, answer questions } \\
\text { about yourself, and underline } \\
\text { the words you recognized } \\
\text { from the list of studies. Report } \\
\text { whether or not they had a } \\
\text { conscious memory of the } \\
\text { learning sequence. }\end{array}$ & $\begin{array}{l}\text { Results for patients } \\
\text { with AD show that } \\
\text { self-reference increased } \\
\text { autonoetic consciousness } \\
\text { only for emotional and } \\
\text { particularly negative trait } \\
\text { adjectives. }\end{array}$ \\
\hline
\end{tabular}

\begin{tabular}{|c|c|c|c|c|c|c|}
\hline 08 & $\begin{array}{l}\text { Kalenzaga, } \\
2014^{46}\end{array}$ & $\begin{array}{l}n=33 \\
A D 18 \\
C G 15\end{array}$ & $\begin{array}{l}64 \text { nouns/words were } \\
\text { divided into four lists } \\
\text { of } 16 \text { words (i.e., } 8 \\
\text { neutral, } 4 \text { positive, } \\
\text { and } 4 \text { negative) } \\
\text { matched for frequency, } \\
\text { concreteness, and } \\
\text { valence. }\end{array}$ & Remember/Know/Guess & $\begin{array}{l}\text { Underline the identified words } \\
\text { from the list of studies and } \\
\text { indicate whether or not they } \\
\text { had a conscious recall of the } \\
\text { learning sequence. }\end{array}$ & $\begin{array}{l}\text { Patients with AD were as } \\
\text { able as normal controls } \\
\text { to benefit from the } \\
\text { emotional content of } \\
\text { information to improve } \\
\text { the recollection of details. }\end{array}$ \\
\hline 09 & $\begin{array}{l}\text { Kalenzaga, } \\
2016^{47}\end{array}$ & $\begin{array}{c}\mathrm{n}=155 \\
\text { YA } 38 \\
\text { OA } 39 \\
\text { VOA } 37 \\
\text { AD } 41\end{array}$ & $\begin{array}{l}64 \text { nouns/words were } \\
\text { divided into four lists } \\
\text { of } 16 \text { words (i.e., } 8 \\
\text { neutral, } 4 \text { positive, } \\
\text { and } 4 \text { negative) } \\
\text { matched for frequency, } \\
\text { concreteness, and } \\
\text { valence. }\end{array}$ & $\begin{array}{l}\text { The task was presented } \\
\text { using the SuperLabPro } \\
\text { software. }\end{array}$ & $\begin{array}{l}\text { Participants had to read } \\
\text { aloud and learn the words, } \\
\text { had to generate a sentence } \\
\text { containing the word, and } \\
\text { after trying four items, the } \\
\text { participants had to remember } \\
\text { the four words and the } \\
\text { corresponding phrases } \\
\text { produced. }\end{array}$ & $\begin{array}{l}\text { The results indicated } \\
\text { that the positivity bias } \\
\text { is most likely to occur } \\
\text { in individuals whose } \\
\text { cognitive functions are } \\
\text { preserved, after long } \\
\text { retention delay, and in } \\
\text { experimental conditions } \\
\text { that do not constrain } \\
\text { encoding.. }\end{array}$ \\
\hline 10 & $\begin{array}{l}\text { Laisney, } \\
2013^{48}\end{array}$ & $\begin{array}{l}\text { AD } 16 \\
\text { CG } 15\end{array}$ & $\begin{array}{c}\text { Preference judgment } \\
\text { task, False-belief task, } \\
\text { and Reading the Mind in } \\
\text { the Eyes test }\end{array}$ & $\begin{array}{l}\text { Reading the Mind in the } \\
\text { Eyes test }\end{array}$ & $\begin{array}{l}\text { Identification in Matching } \\
\text { emotions and Discrimination }\end{array}$ & $\begin{array}{l}\text { We observed impaired } \\
\text { performances by patients } \\
\text { with AD on all the ToM } \\
\text { tasks. } \\
\text { However, affective ToM } \\
\text { seemed affected to a } \\
\text { lesser degree than the } \\
\text { cognitive dimension. }\end{array}$ \\
\hline
\end{tabular}


Table 2. Continuation.

\begin{tabular}{ccccccc}
\hline S. No. $\begin{array}{c}\text { Author, } \\
\text { Year }\end{array}$ & Sample & Stimuli and emotions & Tasks & Control tasks & Results \\
\hline In recognition of \\
Maki,
\end{tabular}

The groups watched four films, namely, one neutral, one positive, and two negative.

\begin{tabular}{|c|c|c|}
\hline & $\mathrm{n}=43$ & Joyful and sad, relaxe \\
\hline $\begin{array}{c}\text { Mograbi, } \\
2012^{50}\end{array}$ & $\begin{array}{l}\text { AD } 22 \\
\text { CG } 21\end{array}$ & $\begin{array}{l}\text { and frightened, calm } \\
\text { and irritated, and } \\
\text { hopeful and hopeless. }\end{array}$ \\
\hline
\end{tabular}
Joy, surprise, fear, sadness, disgust, anger, and contempt were evaluated.
The groups watched four film excerpts, namely, one neutral, one positive, and two negative.
Self-evaluation (How do you feel after watching this?'). For each emotion, participants were asked to rate how they were feeling.
The study indicates that patients show emotional reactions congruent with stimulus valence, but that subjective reactivity is reduced in comparison with healthy older adults for negative material
Two success-failure computerized paradigms were developed, i.e., one based on reaction time and the other on

Frustrated, satisfied; disappointed, satisfied; ashamed, feeling good about himself; and bored, energetic. memory.
Success condition task and one in a failure condition.
Performance evaluation CG 21

Performance evaluation

The results indicated that, relative to controls, patients with $A D$ exhibited impaired awareness of performance, but comparable differential reactivity to failure relative to success tasks, both in terms of self-report and facial expressions.

It was found that, compared to the young adult cohort, the healthy elderly displayed deficits in task-set shielding in the non-emotional but not in the emotional task, whereas PRAD subjects displayed impaired performance in both tasks.
The nonemotional conflict task versus emotiona conflict task.
Photographs of faces and answer options were displayed on a computer screen. Happiness, anger, disgust, fear, and neutral.
Behavioral tasks, facial gender recognition task, and facial emotional expression recognition task.
Participants were asked to determine whether the face was more feminine or masculine.

Participants were asked to select the label that best described the emotional expression
The results indicate that emotion recognition is impaired specifically, rather than as a consequence of global cognitive dysfunction. 
Table 2. Continuation.

\begin{tabular}{|c|c|c|c|c|c|c|}
\hline S. No. & $\begin{array}{c}\text { Author, } \\
\text { Year }\end{array}$ & Sample & Stimuli and emotions & Tasks & Control tasks & Results \\
\hline 16 & $\begin{array}{l}\text { Sava, } \\
2017^{54}\end{array}$ & $\begin{array}{l}\mathrm{n}=63 \\
\mathrm{AD} 17 \\
\mathrm{H} 021 \\
\mathrm{HY} 25 \\
\mathrm{n}=60 \\
\mathrm{AD} 18 \\
\mathrm{H} 021 \\
\mathrm{HY} 21\end{array}$ & $\begin{array}{c}\text { The stimuli were } \\
96 \text { black and white } \\
\text { photographs }(7 \mathrm{~cm} \times \\
5 \mathrm{~cm}) \text { with } 32 \text { human } \\
\text { adult faces against a } \\
\text { gray background (each } \\
\text { one depicting sad, } \\
\text { neutral, and happy } \\
\text { emotional expressions). } \\
\text { Stimuli were selected } \\
\text { from the Montreal Set } \\
\text { of Facial Displays of } \\
\text { Emotion }\end{array}$ & $\begin{array}{l}\text { Delayed matching-to- } \\
\text { sample task, and Emotion } \\
\text { classification task. }\end{array}$ & $\begin{array}{l}\text { Identity discrimination: } \\
\text { indicate who the same } \\
\text { person is. } \\
\text { Emotion identification } \\
\text { (What is the emotion } \\
\text { expressed by the character?) }\end{array}$ & $\begin{array}{l}\text { Results suggest that } \\
\text { the positivity effect } \\
\text { in memory is not } \\
\text { entirely due to the } \\
\text { sense of familiarity for } \\
\text { smiling faces. }\end{array}$ \\
\hline 17 & $\begin{array}{l}\text { Seidl, } \\
2012^{57}\end{array}$ & $\begin{array}{c}47 \\
\text { participants } \\
\text { AD }\end{array}$ & $\begin{array}{l}\text { Photos-IAPS: joy, } \\
\text { surprise joy, surprise, } \\
\text { anger, fear, disgust, } \\
\text { sadness, and contempt. }\end{array}$ & $\begin{array}{l}\text { The participants were } \\
\text { encouraged to focus } \\
\text { their attention on each } \\
\text { presented picture (“Let's } \\
\text { have a look at this one”); } \\
\text { simultaneously, facial } \\
\text { expression was videotaped. }\end{array}$ & $\begin{array}{c}\text { Attentional focus in } \\
\text { either emotion-eliciting or } \\
\text { neutral images }\end{array}$ & $\begin{array}{l}\text { The result that cognitive } \\
\text { deficits are associated } \\
\text { with loss of specific } \\
\text { facial expression point } \\
\text { toward a progressive } \\
\text { loss of control of } \\
\text { facial expressions, } \\
\text { corroborating previous } \\
\text { findings. }\end{array}$ \\
\hline 18 & $\begin{array}{l}\text { Torres, } \\
2015^{58}\end{array}$ & $\begin{array}{l}\text { AD } 30 \\
\text { CG } 30\end{array}$ & $\begin{array}{l}\text { Face drawings } \\
\text { Sadness, happiness, } \\
\text { anger, or surprise }\end{array}$ & $\begin{array}{l}\text { Tasks of identifying faces, } \\
\text { understanding facial } \\
\text { emotions, recognizing } \\
\text { expression of emotion, } \\
\text { and understanding the } \\
\text { nature of a situation and } \\
\text { the appropriate emotional } \\
\text { state that someone would } \\
\text { experience in that situation }\end{array}$ & $\begin{array}{l}\text { The subjects must } \\
\text { select the target of three } \\
\text { other distractors in the } \\
\text { same category. Identity } \\
\text { discrimination: (same/ } \\
\text { different emotion). Indicate } \\
\text { which of the four drawings } \\
\text { best depicts that specific } \\
\text { emotion. And indicate the } \\
\text { drawing that best described } \\
\text { the emotion he had inferred } \\
\text { from the stimulus }\end{array}$ & $\begin{array}{l}\text { The findings suggest } \\
\text { that people with mild } \\
\text { AD have difficulties } \\
\text { making emotional } \\
\text { interpretations of the } \\
\text { environment, mostly } \\
\text { due to their worsening } \\
\text { global cognition. People } \\
\text { with AD had an impaired } \\
\text { ability to perceive } \\
\text { emotions from situations, } \\
\text { particularly when the } \\
\text { emotions presented were } \\
\text { relatively subtle. }\end{array}$ \\
\hline 19 & $\begin{array}{c}\text { Werheid, } \\
2011^{55}\end{array}$ & $\begin{array}{l}\text { AD } 18 \\
\text { CG } 18\end{array}$ & $\begin{array}{l}\text { The stimulus } \\
\text { material consisted } \\
\text { of } 192 \text { portraits of } \\
\text { Caucasian faces } \\
\text { gathered from different } \\
\text { databases and selected } \\
\text { based on computer- } \\
\text { assisted 7-step valence } \\
\text { ratings: happy, neutral, } \\
\text { and angry }\end{array}$ & $\begin{array}{l}\text { The participants' task was } \\
\text { to decide whether they had } \\
\text { previously seen a portrait of } \\
\text { the depicted person. } \\
\text { Finally, on completion of the } \\
\text { task, subjects were asked } \\
\text { to fill out the post-test } \\
\text { PANAS forms }\end{array}$ & $\begin{array}{l}\text { Identity discrimination: } \\
\text { indicate whether same or } \\
\text { different person }\end{array}$ & $\begin{array}{l}\text { The pattern of results } \\
\text { supports the view } \\
\text { that the positivity- } \\
\text { induced recognition } \\
\text { bias represents a } \\
\text { compensatory, gist-based } \\
\text { memory process that is } \\
\text { applied when item-based } \\
\text { recognition fails. }\end{array}$ \\
\hline
\end{tabular}

AD: Alzheimer's disease; ANC: aged normal controls; AS: antisaccades; CG: control group; FB: false belief; HE: healthy elderly; HO: healthy older; HOAs: healthy older adults; HOS: healthy older individuals; HY: healthy young; HYs: healthy young individuals; IAPS: International Affective Picture System; OA: older adults; OCs: older controls; PANAS: Positive and Negative Affect Schedule; PRAD: probable Alzheimer's disease; PS: prosaccades; ToM: Theory of Mind; VOA: very old adults; YA: young adults; YNC: young normal controls. 


\section{Results of assessment tasks}

In eight studies, ${ }^{39,48,49,52-55,57}$ photos were used as stimuli, and the participants were invited to select the frame, which best described the emotional expression represented. No significant difference in performance was observed among healthy older adults and people with AD in two studies. ${ }^{49,54}$ The other six studies concluded that people with $\mathrm{AD}$ had worse performance than the control group, and only one study ${ }^{52}$ related the worse performance to the specific decline in emotion processing. Werheid et al. ${ }^{55}$ attributed the deficit to memory impairment in $\mathrm{AD}$. The other four studies explained the worse performance of people with $\mathrm{AD}$ in more specific neurodegenerative processes in the amygdala and hippocampus and in the general progression of the disease. ${ }^{39,48,53,57}$

Dourado et al..$^{56}$ and Torres et al. ${ }^{58}$ utilized the FACES protocol, which consists of four increasingly difficult facial recognition tasks. The first task investigated the visuoperceptual capacity of identifying faces. The second task examined the comprehension of facial emotions. The third task examined if people with $\mathrm{AD}$ can conceptually recognize the emotional expression, and the fourth, the most complex task, assessed the capacity of understanding the emotional nature of one situation. In the study of Dourado et al. ${ }^{56}$ the results of task 1 have shown a relationship between the impairment of visuoperceptual capacity to identify faces and decreased performance related to cognitive competence. No differences between mild and moderate AD were observed in task 3 . No clinical variables predicted the performance in task 4 among people with mild $\mathrm{AD}$, even after the adjustment to the severity of cognitive decline; however, among people with moderate $\mathrm{AD}$, there was a relationship between task 4 and the emotional recognition domain of awareness of the disease. In the baseline assessment of the study of Torres et al. ${ }^{58}$ there was no relationship between tasks 1, 2, 3, or 4 and the clinical variables. No relation was observed between the global score of FACES and the sociodemographic or clinical variables. After 6 months, the study has shown a significant difference between both assessments on the scores of task 4 . These results show that the emotional impairment in the mild stage of the disease is related to the cognitive impairment and with the progression of AD. However, the study had a small sample and a time span of only 6 months.

To determine the impact of emotion information in early attentional processes among people with $\mathrm{AD}$, Bourgin et al. ${ }^{41}$ applied an eye-screening paradigm and a task that mixed prosaccades and antisaccades with the emotional stimulus. The results suggested that people with AD had difficulties in rapidly and automatically focusing their attention on the emotional characteristics of the faces.

Two studies ${ }^{42,50}$ used video clips as stimuli to assess the capacity of people with $\mathrm{AD}$ on the discrimination and tagging of emotions. Duclos et al. ${ }^{42}$ used the Peter and Mary test, which is composed of short videos with black-and-white images, without sound, and with two characters. This study also applied images with colorful drawings that represented several activities of daily living. The results demonstrated that people with $\mathrm{AD}$ had impairment in decoding emotional mental states of facial expressions.

Mograbi et al. ${ }^{50}$ applied movie excerpts, one neutral, one positive, and two negatives to investigate the influence among people with mild and moderate $\mathrm{AD}$. The results showed that the participants demonstrated reduced reactivity to negative movies, but they exhibited a pattern of facial expressions similar to the control group in all other movie excerpts. Mograbi et al. ${ }^{51}$ investigated the emotional reactivity to success or failure among people with $\mathrm{AD}$ in comparison with a cognitive healthy control group. The study applied two experimental computerized paradigms of manipulation of success and failure, i.e., one based on reaction time and the other on memory. The results of the group of people with $\mathrm{AD}$ have shown a reduction in the awareness about the performance, with difficulties to discriminate between the success and failure conditions. In contrast, they have shown the same levels of emotional reactivity of the control group in both experiences.

Five studies ${ }^{43-47}$ used word lists classified according to the emotional valence as the stimulus. Kalenzaga et al. ${ }^{47}$ reported that people with $\mathrm{AD}$ have shown bias toward positive stimuli, especially in the recognition task after the semantic processing instruction, while, in the group of healthy older adults, the positive preference was observed in both recovering tasks. In the study of Kalenzaga et al., ${ }^{46}$ both people with $\mathrm{AD}$ and cognitive healthy controls may have benefited from the emotional content of the information, with better performance in the retrieval of the information. People with AD were as able as normal controls to benefit from the emotional content of information to improve the recollection of details.

One study ${ }^{44}$ showed that although people with $A D$ had an explicit view of themselves, they only pointed out negative characteristics. Another study ${ }^{45}$ showed that people with $\mathrm{AD}$ produced fewer correct answers when compared with cognitive healthy controls. The data confirm that, in $\mathrm{AD}$, there is a specific impairment in autonoetic awareness and show that declarative memory impairment, which is the characteristic of AD pathology, is mainly an impairment in episodic memory. When a lexical decision 
task was applied ${ }^{43}$ by comparing the automatic semantic effects between people with $\mathrm{AD}$ and cognitive healthy control group, the results reveal that in both groups, there were primary semantic effects to neutral concepts, but they were decreased in comparison with those effects to emotional concepts, especially negative ones. These results have shown that the emotional processing is preserved in $\mathrm{AD}$ and can even help people with $\mathrm{AD}$ to reconnect to the emotional semantic concepts.

\section{Results of the emotional valence assessment tasks}

The eight studies that assessed emotional valence (i.e., positive, negative, and neutral $)^{41,43-47,50,51}$ had differing results. In the study by Bourgin et al., ${ }^{41}$ people with $\mathrm{AD}$ did not show differences in relation to the emotional category in any of the tasks. These results suggest that the early emotional attention is impaired among people with AD.

The analysis of Kalenzaga et al. ${ }^{46}$ indicated that, compared with the control participants who have recognized both emotional and neutral words, people with $\mathrm{AD}$ recognized more neutral than emotional words. This result is in accordance with the studies that reported that people with $\mathrm{AD}$ did not retrieve emotional items better than they retrieve the neutral ones. ${ }^{60-62}$ In the study of Kalenzaga et al., ${ }^{47}$ there was a significant effect of emotional valence, indicating that participants remembered more positive than neutral words. The results suggested that the positivity bias is presented only if the memory performance scores have a certain pattern.

In the study of Mograbi et al., ${ }^{51}$ there were no significant differences among the groups in the positive and negative tasks. Therefore, the affective valence of the failure experience is processed even though there is no awareness about the task performance. In the experiment with movie excerpts, Mograbi et al..$^{50}$ found that participants of the $\mathrm{AD}$ group may have impairments in self-reported reactivity to negative stimuli. All of the emotions and general reactivity were significant, with more positive emotional changes in response to the positive excerpt and negative alteration in the two negative excerpts.

Three studies have shown different results in comparison with the previous ones, which show a more significant effect of the positive emotional valence among people with $\mathrm{AD}$ and controls. Giffard et al. ${ }^{43}$ showed a facilitating effect of the supplementary emotional component in the semantic processing. The primary semantic effects were higher to the negative concepts than to the neutral and positive ones.

The study of Kalenzaga et al. ${ }^{44}$ indicated that, in comparison with other encodings, the negative valence is salient to the self-reference of people with AD. Previous studies that explore the effect of valence on emotional processing show that the information remembered about oneself is generally related to the positive valence. ${ }^{63,64}$

In the results of Kalenzaga et al., ${ }^{45}$ while investigating the interaction between the decoding condition and the emotional valence, there was a contrasting pattern of performance. Only the negative valence had a significant effect on the autonomous awareness of people with $\mathrm{AD}$ in the condition of self-reference. However, the self-reference effect was also marginally significant to the adjectives of positive characteristics, and pairwise comparisons have shown that there was no significant difference between the answer rate to positive and negative adjectives.

\section{Findings of studies about cognitive impairment an emotion processing in Alzheimer's disease}

Seid et al. ${ }^{57}$ suggested that cognitive changes influence the recognition of facial expressions. The study of Bourgin et al.$^{41}$ agreed with this point as it reported that people with $\mathrm{AD}$ had difficulties in quickly and automatically focusing their attention on the emotional features of faces. Other studies ${ }^{39,42,48,52,53}$ have also identified that cognitive impairment and disease severity are related to deficits in the recognition of facial expression, particularly in more complex tasks that supposedly would require more cognitive resources. In agreement, some studies ${ }^{56,58}$ suggest that difficulties in recognizing emotions are more prevalent in relation to more subtle emotions among individuals with $\mathrm{AD}$.

However, the study of Werheid et al..$^{55}$ suggested that the emotion-based aspects of old/new decisions for faces are preserved in people with mild AD. Gifard et al. ${ }^{43}$ and Sava et al. ${ }^{54}$ showed that emotional processing is preserved in $\mathrm{AD}$ and may even help people with AD to link semantically close emotional concepts more tightly. These results are in line with previous findings showing no difference in facial emotional expression processing between healthy older participants and participants of the $\mathrm{AD}$ group, ${ }^{35,65}$ especially for faces with happy expressions. ${ }^{49}$

The results shown by Kalenzaga et $a{ }^{4}{ }^{46}$ corroborate the findings of previous studies ${ }^{44,45}$ and confirm that people with $\mathrm{AD}$ have a specific deficit in the episodic component of memory for words. Furthermore, Kalenzaga et al ${ }^{47}$ indicated that the positivity bias is most likely to occur in individuals whose cognitive functions are preserved, after a long retention delay, and in experimental conditions that do not constrain encoding.

Mograbi et al. ${ }^{50}$ showed that people with AD showed emotional reactions congruent with stimulus valence, but the subjective reactivity is reduced in comparison with healthy older adults for negative material. Mograbi et al. ${ }^{51}$ indicated a dissociation between impaired 
performance judgment and preserved emotional reactivity to failure in $\mathrm{AD}$.

\section{DISCUSSION}

To better understand the impairment in emotion processing in people with $\mathrm{AD}$, this systematic review analyzed 19 studies. The main findings suggest the following: (1) people with AD may have impairments in the ability to process emotions, but there are controversies about the beginning of emotion perception impairment among them, (2) there is not a methodological standard in the assessment of emotion processing, which may influence the results and contribute to a variability and lack of consistency of findings in the area, (3) the studies disagree whether the impairment in emotion processing is related to global cognitive impairment or to a decrease in a more specific system of emotion processing, (4) the impairment in emotion processing may be independent of stimulus or task used in the testing of various emotional aspects, (5) there are discrepancies in identifying emotions; while some studies showed that the emotions with negative valence may be more impaired than the positive emotions, other studies reported that the degree of this impairment may be influenced by disease severity and level of excitement (e.g., anger elicits more excitement and is better perceived than sadness), and (6) the analysis of the effect of emotional valence has shown influence on cognitive performance among people with $\mathrm{AD}$.

\section{The beginning of emotion processing impairment among people with Alzheimer's disease}

The beginning of emotion processing impairment among people with $\mathrm{AD}$ has not been discussed enough in any of the evaluated studies. There is almost a consensus that the abilities of emotion perception are frequently impaired even among people with mild dementia due to the impairment of limbic system. ${ }^{66-69}$ Therefore, the neurodegenerative process among people with $\mathrm{AD}$ may be responsible for increased impairment in emotion perception. ${ }^{70,71}$ However, some studies consider that the emotion processes are relatively preserved in mild dementia, in comparison with other cognitive domains, such as semantic memory. ${ }^{35,37}$ Other studies also support that people with $\mathrm{AD}$ may retain the capacity of understanding the emotion, independently of the decrease in the cognitive capacity, and they remain capable of being involved in nonverbal communication that may occur in their interpersonal relationships. ${ }^{72}$ Nonetheless, only the study reported by Giffard et al. ${ }^{43}$ suggested that emotion processing is relatively preserved in mild dementia, in comparison with other cognitive domains. Conversely, some studies ${ }^{39,42,48,50,52,53,56,58}$ point out that the impairment of emotion processing may start even in the mild cases of $\mathrm{AD}$ due to the cognitive impairment.

We may observe that the results of the reviewed studies highlight the beginning of the impairment of emotion processing in different stages of the disease. However, these discrepancies among studies may be a result of the variability of objectives and different study methodologies, which may influence and hinder the process of identifying the key points. In addition, the complexity of tasks suggests multiple steps/components that could result in failures/low scores, some of which may not be related to the core features of emotional processing. For example, failed naming of emotions based on face stimuli could be tied to emotion processing/recognition or language disruption in semantic networks. Therefore, more longitudinal studies are necessary to identify the exact stage of the disease in which those difficulties occur. Identifying earlier this kind of impairment would be crucial to a differential diagnosis and to the development of strategies of intervention to facilitate communication and emotional expression of people with $\mathrm{AD}$.

\section{Performance in emotional processing in individuals with Alzheimer's disease}

Most studies used traditional methods (i.e., naming of emotions, discrimination, identification, and correspondence) that have been used in the last decade to assess emotion processing. Due to the cognitive competences involved in each of these different procedures, it is understood that the implicit cognitive processes involved in each task may be affected by the disease. Thus, we may highlight that there is not a consensus about the impairment involved in the capacity of decoding emotions among people with $\mathrm{AD}$, as some results show that there are abilities preserved in $\mathrm{AD}$, while others report deficits in this ability. Maybe, these controversies are caused by the variability of stimuli used in the assessment. This diversity may produce bias or inconsistency of results that are sometimes contradictory. For example, Laisney et al. ${ }^{48}$ reported that people with AD may have more difficulties in tasks that involve various cognitive domains, such as language, verbal working memory, and social cognition, in comparison with their difficulties in affective tasks. In contrast, Bourgin et al. ${ }^{41}$ suggest that the early emotional attention is impaired among people with $\mathrm{AD}$ in a technique of sight-screening during a simple cognitive task. Overall, the results have been generally attributed to the characteristic decline in AD. However, we may consider that the lack of standardization 
of assessment instruments to consistently investigate whether people with $\mathrm{AD}$ maintain their preserved capacity of recognition of others emotions as well as the lack of expression of their own emotions may be directly related to their performance.

\section{Capacity of perceiving emotions}

In relation to specific emotions involved in the decoding tasks, some studies investigated the ability to identify specific emotions such as happiness or sadness. Previous findings ${ }^{31,35,73,74}$ highlight that the capacity to process some emotions is preserved in $\mathrm{AD}$ (e.g., happiness and disgust). Other studies highlight that the participants have particular impairment in the decoding of emotions, such as fear. ${ }^{6,25,75}$ There is contrasting evidence using a longitudinal design to assess the recognition of facial expressions among people with $\mathrm{AD}$. A study ${ }^{58}$ reported that the participants continued to appropriately recognize the basic emotions represented in simple drawings but had more difficulties in a more complex task (i.e., identifying the emotional state that would be experimented in a particular situation). However, the results of Sapey-Triomphe et al. ${ }^{53}$ in a cross-sectional design showed that people with $A D$ were impaired in the recognition of each one of the various basic emotions (i.e., anger, fear, happiness, and, on a lower degree, disgust). The decline in the ability of emotional decoding was significantly related in $\mathrm{AD}$ to all types of emotions. There are assumptions that the performance in the recognition of emotions is related to the volume of expected brain structures. However, the performance on the recognition of emotions was negatively related to the majority of volumes in the gray matter in the interest regions. In particular, the performance in recognition of fear was negatively related to the amygdala volume. ${ }^{53}$ These data contradict other studies ${ }^{76,77}$ that associated the amygdala function in the processing of fear. Various studies highlight the central role of the amygdala in the emotion processing ${ }^{17,19,20,78}$ and support the hypothesis that the amygdala is involved in the process of the response of the stimuli to several emotions, which may explain why the decline in the emotional coding of people with $\mathrm{AD}$ is not restricted to one specific emotion such as fear. ${ }^{79}$ It is reasonable to consider that the impact of the neurodegenerative process associated with $\mathrm{AD}$ may affect the identification of specific emotions. This point may indicate that regional involvement in each kind of emotion recognition follows distinct patterns, which supports the localizationist view that postulates unique regional networks for each emotion. ${ }^{17}$ Due to the progressive nature of $\mathrm{AD}$, longitudinal studies with the support of neuroimaging could provide more comprehension of the change patterns in the process of discrimination of emotions among people with $\mathrm{AD}$.

\section{Relationship between emotion processing and cognitive domains}

The relationship between deficits in emotion processing and cognitive functioning in people with $\mathrm{AD}$ is still underestimated. Although decline in emotion perception may occur, the impact of the global cognitive decline associated with $\mathrm{AD}$ across studies varies. Some studies suggest that global cognitive performance affects the performance on tasks of emotion perception among people with $\mathrm{AD}$, but other studies show a decline in the recognition of emotion, independently of the cognitive performance. We hypothesized that these results may be due to the considerable heterogeneity of methods and assessment of cognitive and emotional processes.

Few studies investigate the relationship between cognitive impairment, the severity of the disease, and the impact on the perception of emotions. ${ }^{53,56,58}$ Moreover, some authors support that emotion processing impairment exists independently of disease severity. Various tools have been used to assess cognitive functions among people with $\mathrm{AD}$. However, most studies have applied the MMSE to assess the association between cognitive state and emotion processing in tasks and procedures. The emotion decoding performance in $\mathrm{AD}$ was significantly related to MMSE scores, but some studies did not find this significant relation. Therefore, the strength of these results may be cautiously considered since the MMSE is a tool for screening cognitive decline, susceptible to education and socioeconomic status. Studies that only include screening tests may have limited validity in their findings. A comprehensive neuropsychological assessment of different cognitive domains would have more power to disentangle, in which cognitive functions are more or less related to the emotional processing in $\mathrm{AD}$. Thus, we may consider that the relationship between emotion processing and global cognitive capacity is not clear.

\section{The effect of different emotions in Alzheimer's disease}

The research about emotional valence and its impact on emotion and cognitive processing in $\mathrm{AD}$ has been explored, and the results are inconsistent. Some studies have shown the existence of a positive bias. ${ }^{46,47,49,55}$ For example, the study of Werheid et al. ${ }^{55}$ shows that the positive bias is really present and affects the performance of people with $\mathrm{AD}$, as well as in cognitive healthy old adults. These data represent evidence of preservation of emotion processing in people with $\mathrm{AD}$. However, we may highlight that the results of studies have shown significant difference among assessed groups, and, therefore, we may consider that, in general, there is a decline in the cognitive capacities of processing emotions and responding to them.

Our study has some limitations that should be considered. There are a limited number of studies that 
investigate emotional processing in $\mathrm{AD}$, and many of them have low statistical power. In addition, the variety of objectives and methodologies in the reviewed studies hinder the identification of key points. More research is necessary, therefore, to establish the attributions of emotions in relation to cognition.

Our main target was to analyze the relationship between emotion processing and cognition in mild and moderate AD. We concluded that there is evidence that suggests the presence of emotion processing deficits even among people with mild AD. However, the relationship between emotion processing and cognition is not clear. The existing literature presents contradicting results and reports emotion processing impairment in relation to cognition but does not discuss the possible implications of this impairment in social (dys)function. Crucially, emotion processing impairment may negatively impact the well-being of people with $\mathrm{AD}$ and their caregivers, which could be an important discussion for future studies.

More longitudinal studies are necessary to investigate the relationship between cognition and emotion processing during the disease progression. Potentially confusing factors such as global cognitive decline, presence of neuropsychiatric symptoms, and mood must be observed. Studies that include neuroimaging data, such as volumetric analyses of the amygdala, may also enhance the comprehension of the processes involved in emotion recognition among people with $\mathrm{AD}$. Therefore, the progressive neuropathological alterations that characterize the disease may impact on emotion processing, and a sensitive focus on this process may help to refine interventions that encompass social interaction.

Authors' contributions. RR: literature search and writing - original draft. RLSC: review and editing. MCND: conceptualization, review literature search, and review and editing.

\section{ACKNOWLEDGMENTS}

The authors thank Dr Sara Mason and Dr Shelley Peery, from the Research and Editing Consulting Program (RECP) coordinated by Prof. Mary Beth Spitznagel, associate professor of the Department of Psychological Sciences of the Kent State University, for the careful revision of the manuscript and editing for English language.

\section{REFERENCES}

1. Cadieux N, Greve KW. Emotion processing in Alzheimer's Disease. J Int Neuropsychol Soc. 1997;3(5):411-9. https://doi.org/10.1017/ S1355617797004116

2. McRae K, Misra S, Prasad AK, Pereira SC, Gross JJ. Bottom-up and top-down emotion generation: implications for emotion regulation. Soc Cogn Affect Neurosci. 2011;7(3):253-62. https://doi.org/10.1093/scan/nsq103

3. Circelli KS, Clark US, Cronin-Golomb A. Visual scanning patterns and executive function in relation to facial emotion recognition in aging. Neuropsychol Dev Cogn B Aging Neuropsychol Cogn. 2013;20(2):148-73. https://doi.org/10.1080/13825585.2012.675427

4. Lambrecht L, Kreifelts B, Wildgruber D. Age-related decrease in recognition of emotional facial and prosodic expressions. Emotion. 2012;12(3):529-39. https://doi.org/10.1037/a0026827

5. Lima CF, Alves T, Scott SK, Castro SL. In the ear of the beholder: How age shapes emotion processing in nonverbal vocalizations. Emotion. 2014;14(1):145-60. https://doi.org/10.1037/a0034287

6. Spoletini I, Marra C, Iulio FD, Gianni W, Sancesario G, Giubilei F, et al. Facial emotion recognition deficit in amnestic mild cognitive impairment and Alzheimer disease. Am J Geriatr Psychiatry. 2008;16(5):389-98. https://doi.org/10.1097/JGP.0b013e318165dbce

7. Weiss EM, Kohler CG, Vonbank J, Stadelmann E, Kemmler G, Hinterhuber $\mathrm{H}$, et al. Impairment in emotion recognition abilities in patients with mild cognitive impairment, early and moderate Alzheimer disease compared with healthy comparison subjects. Am J Geriatr Psychiatry. 2008;16(12):974-80. https://doi.org/10.1097/ JGP.0b013e318186bd53

8. Henry JD, von Hippel W, Molenberghs P, Lee T, Sachdev PS. Clinical assessment of social cognitive function in neurological disorders. Nat Rev Neurol. 2016;12(1):28-39. https://doi.org/10.1038/nrneurol.2015.229

9. Kennedy DP, Adolphs R. The social brain in psychiatric and neurological disorders. Trend Cogn Sci. 2012;16(11):559-72. https://doi.org/10.1016/j. tics.2012.09.006

10. Allender J, Kasniak A. Processing of emotional cues in patients with dementia of the Alzheimer's type. Int J Neurosci. 1989;(3-4):147-55. https:// doi.org/10.3109/00207458908986252
11. Hargrave R, Maddock RJ, Stone V. Impaired recognition of facial expression of emotion in Alzheimer's disease. J Neuropsychiatry Clin Neurosci. 2002;14(1):64-71. https://doi.org/10.1176/jnp.14.1.64

12. Ekman P, Friesen WV. Constants across cultures in the face and emotion. J Pers Soc Psychol. 1971;17(2):124-9. ttps://psycnet.apa.org/doi/10.1037/ h0030377

13. McCade D, Savage G, Naismith SL. Review of emotion recognition in mild cognitive impairment. Dement Geriatr Cogn Disord. 2011;32(4):257-66. https://doi.org/10.1159/000335009

14. Ruffman T, Henry JD, Livingstone V, Phillips LH. A meta-analytic review of emotion recognition and aging: implications for neuropsychological models of aging. Neurosci Biobehav Rev. 2008;32(4):863-81. https://doi. org/10.1016/j.neubiorev.2008.01.001

15. Poulin P, Zakzanis KK. In vivo neuroanatomy of Alzheimer's disease: evidence from structural and functional brain imaging. Brain Cogn. 2002;49(2):220-5. PMID: 15259395

16. Rosen HJ, Wilson MR, Schauer GF, Allison S, Gorno-Tempini ML, Pace-Savitsky C, et al. Neuroanatomical correlates of impaired recognition of emotion in dementia. Neuropsychologia. 2006;44(3):365-73. https://doi. org/10.1016/j.neuropsychologia.2005.06.012

17. Adolphs R. Neural systems for recognizing emotion. Curr Opin Neurobiol. 2002;12(2):169-77. https://doi.org/10.1016/S0959-4388(02)00301-X

18. Adolphs R, Spezio M. Role of the amygdala in processing visual social stimuli. Prog Brain Res. 2006;156:363-78. https://doi.org/10.1016/ S0079-6123(06)56020-0

19. Blair RJ, Morris JS, Frith CD, Perrett DI, Dolan RJ. Dissociable neural responses to facial expressions of sadness and anger. Brain. 1999;122(Pt 5):883-93. https://doi.org/10.1093/brain/122.5.883

20. Vuilleumier P, Pourtois G. Distributed and interactive brain mechanisms during emotion face perception: Evidence from functional neuroimaging. Neuropsychologia. 2007;45(1):174-94. https://doi.org/10.1016/j.neuropsychologia.2006.06.003

21. Braak H, Braak E. Neuropathological stageing of Alzheimer-related changes. Acta Neuropathol. 1991;82(4):239-59. https://doi.org/10.1007/ BF00308809 
22. Bruen PD, McGeown WJ, Shanks MF, Venneri A. Neuroanatomical correlates of neuropsychiatric symptoms in Alzheimer's disease. Brain. 2008;131(Pt 9):2455-63. https://doi.org/10.1093/brain/awn151

23. H oŕínek D, Varjassyová A, Hort J. Magnetic resonance analysis of amygdalar volume in Alzheimer's disease. Curr Opin Psychiatry. 2007;20(3):273-7. https://doi.org/10.1097/YCO.0b013e3280ebb613

24. McCade D, Savage G, Guastella A, Lewis SJ, Naismith SL. Emotion recog nition deficits exist in mild cognitive impairment, but only in the amnestic subtype. Psychol Aging. 2013;28(3):840-52. https://doi.org/10.1037/ a0033077

25. Henry JD, Ruffman T, McDonald S, O'Leary MA, Phillips LH, Brodaty H, et al. Recognition of disgust is selectively preserved in Alzheimer's disease. Neuropsychologia. 2008;46(5):1363-70. https://doi.org/10.1016/j. neuropsychologia.2007.12.012

26. McLellan T, Johnston L, Dalrymple-Alford J, Porter R. The recognition of facial expressions of emotion in Alzheimer's disease: a review of findings. Acta Neuropsychiatr. 2008;20(5):236-50. https://doi.org/10.1111/j. 1601-5215.2008.00315.x

27. Phillips LH, Scott C, Henry JD, Mowat D, Bell JS. Emotion perception in Alzheimer's disease and mood disorder in old age. Psychol Aging. 2010;25(1):38-47. https://doi.org/10.1037/a0017369

28. García-Rodríguez B, Fusari A, Rodríguez B, Hernández JMZ, Ellgring $H$. Differential patterns of implicit emotional processing in Alzheimer's disease and healthy aging. J Alzheimers Dis. 2009;18(3):541-51. https:// doi.org/10.3233/JAD-2009-1161

29. Klein-Koerkamp Y, Beaudoin M, Baciu M, Hot P. Emotional decoding abilities in Alzheimer's disease: a meta-analysis. J Alzheimers Dis. 2012;32(1):109-25. https://doi.org/10.3233/JAD-2012-120553

30. Kumfor F, Sapey-Triomphe L-A, Leyton CE, Burrell JR, Hodges JR, Piguet O. Degradation of emotion processing ability in corticobasal syndrome and Alzheimer's disease. Brain. 2014;137(Pt 11):3061-72. https://doi. org/10.1093/brain/awu246

31. Guaita A, Malnati M, Vaccaro R, Pezzati R, Marcionetti J, Vitali SF, et al. Impaired facial emotion recognition and preserved reactivity to facial expressions in people with severe dementia. Arch Gerontol Geriatr. 2009;49 Suppl 1:135-46. https://doi.org/10.1016/j.archger.2009.09.023

32. Burnham H, Hogervorst E. Recognition of facial expressions of emotion by patients with dementia of the Alzheimer type. Dement Geriatr Cogn Disord. 2004;18(1):75-9. https://doi.org/10.1159/000077813

33. Drapeau J. Neuropsychological approach of emotion recognition in the early dementia of the Alzheimer type (DAT). Sherbrooke: Department Gerontology, Sherbrooke, Canada, Université de Sherbrooke; 2009.

34. Lavenu I, Pasquier F, Lebert F, Petit H, der Linden MV. Perception of emotion in frontotemporal dementia and Alzheimer disease. Alzheimer Dis Assoc Disord. 1999;13(2):96-101. https://doi.org/10.1097/00002093199904000-00007

35. Bucks RS, Radford SA. Emotion processing in Alzheimer's disease. Aging Ment Health. 2004;8(3):222-32. https://doi.org/10.1080/136078604100 01669750

36. Miller LA, Mioshi E, Savage S, Lah S, Hodges JR, Piguet O. Identifying cognitive and demographic variables that contribute to carer burden in dementia. Dement Geriatr Cogn Disord. 2013;36(1-2):43-9. https://doi. org/10.1159/000347146

37. Albert MS, Cohen C, Koff E. Perception of affect in patients with dementia of the Alzheimer type. Arch Neurol. 1991;48(8):791-5. https://doi. org/10.1001/archneur.1991.00530200027013

38. Roudier M, Marcie P, Grancher A-S, Tzortzis C, Starkstein S, Boller F. Discrimination of facial identity and of emotions in Alzheimer's Disease. J Neurol Sci. 1998;154(2):151-8. https://doi.org/10.1016/s0022 510x(97)00222-0

39. Daley RT, Sugarman MA, Shirk SD. Spared emotional perception in patients with Alzheimer's disease is associated with negative caregiver outcomes. Aging Ment Health. 2018;22(5):595-602. https://doi.org/10. 1080/13607863.2017.1286457

40. Hong QN, Pluye P, Fàbregues S, Bartlett G, Boardman F, Cargo M, et al Mixed Methods Appraisal Tool (MMAT). Educ Inf. 2018;34(4):285-91. https://doi.org/10.3233/EFl-180221

41. Bourgin J, Guyader N, Chauvin A, Juphard A, Sauvée M, Moreaud O, et al. Early Emotional Attention is Impacted in Alzheimer's Disease: An Eye-Tracking Study. J Alzheimers Dis. 2018;63(4):1445-58. https://doi. org/10.3233/JAD-180170

42. Duclos $H$, Bejanin A, Eustache F, Desgranges B, Laisney M. Role of context in affective Theory of Mind in Alzheimer's disease. Neuropsychologia. 2018;19:363-72. https://doi.org/10.1016/j.neuropsychologia.2018.08.025

43. Giffard B, Laisney M, Eustache F, Desgranges B. Can the emotional connotation of concepts modulate the lexico-semantic deficits in Al- zheimer's disease? Neuropsychologia. 2009;47(1):258-67. https://doi. org/10.1016/j.neuropsychologia.2008.07.013

44. Kalenzaga S, Clarys D. Self-referential processing in Alzheimer's disease: Two different ways of processing self-knowledge? J Clin Exp Neuropsychol. 2013;35(5):455-71. https://doi.org/10.1080/13803395.2013.789485

45. Kalenzaga S, Bugaïska A, Clarys D. Self-reference effect and autonoetic consciousness in Alzheimer disease. Alzheimer Dis Assoc Disord. 2013;27(2):116-22. https://doi.org/10.1097/WAD.0b013e318257dc31

46. Kalenzaga S, Piolino P, Clarys D. The emotional memory effect in Alzheimer's disease: Emotional words enhance recollective experience similarly in patients and control participants. Cogn Emotion. 2014;29(2):342-50. https://doi.org/10.1080/02699931.2014.907127

47. Kalenzaga S, Lamidey V, Ergis A-M, Clarys D, Piolino P. The positivity bias in aging: Motivation or degradation? Emotion. 2016;16(5):602-10. https:// doi.org/10.1037/emo0000170

48. Laisney M, Bon L, Guiziou C, Daluzeau N, Eustache F, Desgranges B. Cognitive and affective Theory of Mind in mild to moderate Alzheimer's disease. J Neuropsychol. 2013;7(1):107-20. https://doi.org/10.1111/j. 1748-6653.2012.02038.x

49. Maki $Y$, Yoshida $H$, Yamaguchi $T$, Yamaguchi $H$. Relative preservation of the recognition of positive facial expression "happiness" in Alzheimer disease. Int Psychogeriatr. 2013;25(1):105-10. https://doi.org/10.1017/ S1041610212001482

50. Mograbi DC, Brown RG, Morris RG. Emotional reactivity to film material in Alzheimer's disease. Dement Geriatr Cogn Disord. 2012;34(5-6):351-9. https://doi.org/10.1159/000343930

51. Mograbi DC, Brown RG, Salas C, Morris RG. Emotional reactivity and awareness of task performance in Alzheimer's disease. Neuropsychologia. 2012;50(8):2075-84. https://doi.org/10.1016/j.neuropsychologia.2012.05.008

52. Monti JM, Weintraub S, Egner T. Differential age-related decline in conflict-driven task-set shielding from emotional versus non-emotional distracters. Neuropsychologia. 2010;48(6):1697-706. https://doi.org/10.1016/j. neuropsychologia.2010.02.017

53. Sapey-Triomphe L-A, Heckemann RA, Boublay N, Dorey J-M, Hénaff M-A, Rouch I. Neuroanatomical correlates of recognizing face expressions in mild stages of Alzheimer's disease. PLoS One. 2015;10(12):e0143586. https://doi.org/10.1371/journal.pone.0143586

54. Sava A-A, Krolak-Salmon P, Delphin-Combe F, Cloarec M, Chainay H. Memory for faces with emotional expressions in Alzheimer's disease and healthy older participants: positivity effect is not only due to familiarity. Neuropsychol Dev Cogn B Aging Neuropsychol Cogn. 2017;24(1):1-28. https://doi.org/10.1080/13825585.2016.1143444

55. Werheid K, McDonald RS, Simmons-Stern N, Ally BA, Budson AE. Familiar smiling faces in Alzheimer's disease: Understanding the positivity-related recognition bias. Neuropsychologia. 2011;49(1):2935-40. https://doi. org/10.1016/j.neuropsychologia.2011.06.022

56. Dourado MC, Torres MM, Simões NJ, Alves G, Alves C. Facial expression recognition patterns in mild and moderate Alzheimer's disease. J Alzheimers Dis. 2019;69(2):539-49. https://doi.org/10.3233/JAD-181101

57. Seidl U, Lueken U, Thomann PA, Kruse A, Schröder J. Facial expression in Alzheimer's disease. Am J Alzheimers Dis Other Dement. 2012;27(2):1006. https://doi.org/10.1177/1533317512440495

58. Torres B, Santos RL, Sousa MFB. de, Simões Neto JP, Nogueira MML, Belfort TT, et al. Facial expression recognition in Alzheimer's disease: a longitudinal study. Arq Neuro-Psiquiatr. 2015;73(5):383-9. https://doi. org/10.1590/0004-282X20150009

59. Bonin P, Méot A, Aubert L, Malardier N, Niedenthal P, Capelle-Toczek MC. Normes de concrétude, de valeur d'imagerie, de fréquence subjective et de valence émotionnelle pour 866 mots. Annee Psychol. 2003;103(4):65594. https://doi.org/ 10.3406/psy.2003.29658

60. Hamann SB, Monarch ES, Goldstein FC. Memory enhancement for emotional stimuli is impaired in early Alzheimer's disease. Neuropsychology. 2000;14(1):82-92. https://doi.org/10.1037//0894-4105.14.1.82

61. Kensinger EA, Brierley B, Medford N, Growdon JH, Corkin S. Effects of normal aging and Alzheimer's disease on emotional memory. Emotion. 2002;2(2):118-34. https://doi.org/10.1037/1528-3542.2.2.118

62. Kensinger EA, Corkin S. Two routes to emotional memory: Distinct neural processes for valence and arousal. Proc Natl Acad Sci USA. 2004;101(9):3310-5. https://doi.org/10.1073/pnas.0306408101

63. Mezulis AH, Abramson LY, Hyde JS, Hankin BL. Is there a universal positivity bias in attributions? A meta-analytic review of individual, developmental, and cultural differences in the self-serving attributional bias. Psychol Bull. 2004;130(5):711-47. https://doi.org/10.1037/0033-2909.130.5.711

64. Pahl S, Eiser JR. Valence, comparison focus and self-positivity biases. Does it matter whether people judge positive and negative traits? Exp Psychol. 2005;52(4):303-10. https://doi.org/10.1027/1618-3169.52.4.303 
65. Fernandez-Duque D, Black SE. Impaired recognition of negative facial emotions in patients with frontotemporal dementia. Neuropsychologia. 2005;43(11):1673-87. https://doi.org/10.1016/j.neuropsychologia.2005.01.005

66. Chan D, Fox NC, Scahill RI, Crum WR, Whitwell JL, Leschziner G, et al. Patterns of temporal lobe atrophy in semantic dementia and Alzheimer's disease. Ann Neurol. 2001;49(4):433-42. PMID: 11310620

67. Jack CR Jr. Medial temporal lobe volumetrics in traumatic brain injury. AJNR Am J Neuroradiol. 19 97:18(1):25-8. PMID: 9010516

68. Miller MI, Younes L, Ratnanather JT, Brown T, Trinh H, Lee DS, et al. Amygdalar atrophy in symptomatic Alzheimer's disease based on diffeomorphometry: The BIOCARD cohort. Neurobiol Aging. 2015;36(Suppl 1):S3-S10. https://doi.org/10.1016/j.neurobiolaging.2014.06.032

69. Yi HA, M€oller C, Dieleman N, Bouwman FH, Barkhof F, Scheltens P, et al. Relation between subcortical grey matter atrophy and conversion from mild cognitive impairment to Alzheimer's disease. J Neurol Neurosurg Psychiatry. 2016;87(4):425-32. https://dx.doi.org/10.1136/jnnp-2014309105

70. Mende-Siedlecki P, Said CP, Todorov A. The social evaluation of faces: A meta-analysis of functional neuroimaging studies. Soc Cogn Affect Neurosci. 2013;8(3):285-99. https://doi.org/10.1093/scan/nsr090

71. Pessoa L, Adolphs R. Emotion processing and the amygdala: From a 'low road' to 'many roads' of evaluating biological significance. Nat Rev Neurosci. 2010;11(11):773-83. https://doi.org/10.1038/nrn2920

72. Budson AE, Todman RW, Chong H, Adams EH, Kensinger EA, Krangel TS, et al. False recognition of emotional word lists in aging and Alzheimer's di- sease. Cogn Behav Neurol. 2006;19(2):71-8. https://doi.org/10.1097/01. wnn.0000213905.49525.d0

73. Luzzi S, Piccirilli M, Provinciali L. Perception of emotions on happy/sad chimeric faces in Alzheimer disease: relationship with cognitive functions. Alzheimer Dis Assoc Disord. 2007;21(2):130-5. https://doi.org/10.1097/ WAD.0b013e318064f445

74. Yamaguchi T, Maki Y, Yamaguchi H. Yamaguchi facial expression-making task in Alzheimer's disease: a novel and enjoyable make-a-face game. Dement Geriatr Cogn Dis Extra. 2012;2(1):248-57. https://doi.org/10.1159/000339425

75. Kohler CG, Anselmo-Gallagher G, Bilker W, Karlawish J, Gur RE, Clark $\mathrm{CM}$. Emotion-discrimination deficits in mild Alzheimer disease. Am J Geriatr Psychiatry. 2005;13(11):926-33. https://doi.org/10.1176/appi.ajgp.13.11.926

76. Fusar-Poli P, Placentino A, Carletti F, Landi P, Allen P, Surguladze S, et al. Functional atlas of emotional faces processing: a voxel-based meta-analysis of functional magnetic resonance imaging studies. J Psychiatry Neurosci. 2009;34(6):418-32. PMCID: PMC2783433

77. Vytal K, Hamann S. Neuroimaging support for discrete neural correlates of basic emotions: a voxel-based meta-analysis. J Cogn Neurosci. 2010;22(12):2864-85. https://doi.org/10.1162/jocn.2009.21366

78. Holt DJ, Weiss AP, Rauch SL, Wright Cl, Zalesak M, Goff D C, et al. Sustained activation of the hippocampus in 2response to fearful faces in schizophrenia. Biol Psychiatry. 2005;57(9):1011-9. https://doi.org/10.1016/j. biopsych.2005.01.033

79. Sander D, Grafman J, Zalla T. The human amygdala: an evolved system for relevance detection. Rev Neurosci. 2003;14(4):303-16. https://doi. org/10.1515/revneuro.2003.14.4.303 